\title{
Song as a Register for Black Feminist Theatre- Making Aesthetic
}

\author{
Refiloe Lepere ${ }^{1 \text { * }}$ \\ 1 Department of Performing Arts, Tshwane University of Technology, South Africa \\ *leperer@gmail.com \\ Received: 1 September 2020 Accepted: 8 February 2021 Published: 20 April 2021 \\ Editors: Britton Williams, Leah Gipson Reviewers: Sinethemba Makanya, Marisol Norris
}

\begin{abstract}
This article looks at the play, Dipina tsa Monyanyako, which was made with a group of domestic workers in South Africa. The article explores how song is used as a strategy to locate ways of creating and making in South Africa. Song therefore registers a historical way of imagining and how marginalised groups; women have written themselves into history.

The production is a creative conversation where song is used to express care and anger in everyday life. Current approaches to knowledge production are inadequate in capturing song, poetics, and interpreting the forms of performances black women engage. The article makes a case for song as a form of black feminist theatre-making aesthetic. Using Dipina tsa Monyanyako, I argue that songs, silence, sighs have important methodological implications for arts-based processes and research.

In post-apartheid South Africa, performances are characterized by constant aesthetic reinvention. From precolonial expressions of life to protest theatre, performance aesthetics have been a way of revealing everyday life and struggles. For black women, theatre becomes the meeting place of the expression of their lives and a space of reflection and analysis of those lives, even though, historically, the presence of black women in theatre has been minimal. The creation of Dipina tsa Monyanyako allowed for the emergence of women as empowered subjects, and song became a portal for collective transformation.
\end{abstract}

Keywords: Black Feminist Theatre Aesthetic, Black Aesthetics, Songs and Silence, Song and Struggle

How does one listen for the groans and cries, the undecipherable songs, the crackle of fire in the cane fields, the laments for the dead, and the shouts of victory, and then assign words to all of it? (Hartman 2008, p. 3)

When we reject dominant western oppositional hierarchies of silence and speech and instead adopt frameworks where [songs] words, silence, dreams, gestures, tears all exist interdependently, and within the same interpretive field, we find that the mute always speak. (Motsemme, 2004, p. 910) 
Saidiya Hartman and Nthabiseng Motsemme write that we must read gestures, sighs, songs, silences and cries, made by women as knowledge objects (Motsemme, 2004). They suggest that these wordless actions are an avenue used by women to make new knowledge. As a theatre-maker and drama therapist, gestures and bodily acts are important in my work. They are the modes in which I get to interact with actor-participants. More importantly, in a place like South Africa where black women have been "simultaneously made hypervisible and invisible through systemic violence to which they have been subjected" (Gqola 2006, p. 45), wordless actions are essential in making meaning and understanding human experiences.

This article looks at elements of the play Dipina tsa Monyanyako, made with a group of domestic workers in South Africa, and how their use of song borrows from historical forms of imagining and writing alternative ways of being visible. The production process was a creative conversation about song to express anger in everyday life. In this article, I analyze the songs that were sung in the play for their thematic traits, how they speak to collective memory, and how they bring into focus black women as subjects, their investment in both domestic space and public spheres. Current approaches to knowledge production are inadequate in capturing song as theatrical poetics, and interpreting it as a form of creative making that black women are engaged in. The article makes a case for song as a form of black feminist theatre-making aesthetic. Using Dipina tsa Monyanyako, I argue that songs, silence, sighs have important methodological implications for arts-based processes and research. This article makes a case for songs as black aesthetic; as a way of "depicting individual, private experience, a sphere of black agency with broad communal implications" (Thorsson, 2015, p. 149). Dipina tsa Monyanyako, created in June 2018, is a political and poetic contribution to women's embodied resistance.

\section{Commentary on roles}

I first met BoMme ${ }^{1}$ BaBerrario when one of my colleagues introduced me to the group. They had relayed to her (my colleague) that they wanted to do a play. I was brought in as someone to help create a play with the women. They wanted to create a play about HIV/AIDS awareness as it was nearing December 1st. I agreed to help them with the play. ${ }^{2}$ The group wanted to create a piece that would honor family members, loved ones and friends affected and infected with HIV. They also wanted to create a play for awareness for their children, whom they do not see and talk to as often. They wanted the play to say the things they were unable to say in the few, short moments they had at home. Most women in the group worked as domestic workers but others were guardians at the local nursery school or cleaners at a school, and two were drivers and messengers at a local courier company. The ages in the group varied from 25-year-olds to an 88-year-old woman. The size of the group fluctuated between 20-30 participants, depending on the day, week, and season. In one of our sessions, I asked them, what is the point of their meetings?

We want to be self-sufficient women. We came here to Berarrio seeking support to be able to deal with life; we want to be able to handle our own business, (Mathilda one of the oldest members in HBBO, 2018).

When we first started working together, I wanted to create plays that would speak to BoMama's worker issues. I asked them why they were not organising themselves as workers to seek worker rights. Mama Sylvia, who had been a domestic worker for 50 years, replied that the unions do not help them. "They cause trouble for us," she had said. As a social activist, this was a blow to my project; however, after much thought and observation, I realised there were deliberate choices that had been made throughout our time. Silence was used to assert their agency on what should be presented and how they want to be represented. This article explores how song, a vocal exercise, is used. It is also good to note how silence can reveal what consciousness and subjectivity mean for South African women. The world puts currency on our abilities to speak, but 
silence offers another effort of legibility (Motsemme, 2004). Therefore, the aim of my work had to shift to collaboration. The questions left for me were: What exactly would an ethical, caring practice for performers and audience look like? What is the role of silence in showing and practicing kindness and care, and how does this impact the aesthetics of a performance? Dipina became the collaborative culmination of practicing care and kindness in rehearsals, choices and performance.

In reflecting on my role in the group, I was an outsider that facilitated a creative process. The reason was that I wanted to allow for BoMama to share their own artistic practice, which was mainly song. The play was not written out as it did not have one author. It was performed to an audience of BoMama's choosing; this included friends and family members. The play was situated in the tradition of asserting black women's agentic claim to gesture, creating and communicating in a myriad of ways.

\section{Four-part-harmony: Invoking a black feminist aesthetic}

Monyanyako is a Sesotho word meaning choral music. It is defined as:

Mmino wa batho ba bangata, o binwang ka dikarolo tsa mantswe a fapaneng, o hlokang diletswa; pina e binwang ke sehlopha sa batho [It is music sung by a group of people in a choral arrangement; different voices sing in four-part harmony: soprano, alto, tenor and bass]. (Futhwa, 2011, p. 68)

The tradition of choral music in South Africa is long. The famous quote by jazz pianist Abdullah Ibrahim, in the film Amandla, says that "the revolution in South Africa is the only revolution anywhere in the world that was done in four-part harmony" (Hirsh, 2003). Composer, musician and researcher Neo Muyanga (2015) describes the long history of song in South Africa, from religious rites to protest, and how choral music led people to contemplate their lives, imagining being healthier, happier and better citizens. The play was named Dipina tsa Monyanyako-Songs of Happiness-by the participants because they wanted to sing and tell stories. The stories were sad, but they wanted the songs to not be harrowing.

We don't want to sing sad songs. We want to sing songs about joy (Mama Sylvia, one of the oldest members in HBBO, 2018).

For Mama Sylvia, sad songs included religious songs-Difela. They had suggested that "Monyanyako" meant party. We all assumed the word came from the phrase, "nyakallo"-meaning to be happy. Songs were a big feature in the group. We started each session with a song and ended in a song. We sang church songs and closed off with praise or worship songs. These moments were accompanied by long silences. The songs were exploratory techniques towards creating a play that was not a musical but was mainly song and about song. Our rehearsals or development sessions were hourlong, where we focused on how the songs revealed histories or biographical information about all of us.

Songs in South Africa are an integral part of everyday life. They have a strong presence in living the everyday; in song, people express their anger and dissatisfaction in protests against the ruling parties. Historically, songs were an important component of political mobilization. Song functions not only to entertain or to "umthokozisa, odabukileyo" [comforts the hurts], as the song goes, but also functions to unite a group of people who sing together. They also function as reflection and intervention (Mkhoma, 2017). Song also reveals historical and contemporary complexities for conscientization. It links present singers to past singers who also used the same or similar song to critique social disparities and self-exploration. Kenyan writer Ngugi wa Thiongo, in arguing for a language for African Theatre, suggests that song is an integral gesture in everyday life. "Song and dance are not just decorations, but they are an integral part of a conversation, that drinking session, that ritual, that ceremony" (Thiongo, 1986, p. 45). Song and dance is the staple of weddings, funerals, soccer matches, any kind of gathering of two or more people in South Africa. Singing, dancing, and drumming. 
This is part of everyday life, part of communal living, and rites of passage. In my experience, no occasion occurs without vocal music of some kind. Through music, varied concerns about life, joys, and tragedies are expressed. With the advent of colonialism and apartheid, collective singing became a more public collective practice to speak back to power.

Post-apartheid, South African drama, theatre, and performances make use of song. A process of constant aesthetic reinvention also characterizes performance in the changing country. The historical oppressive and exploitative nature of apartheid was such that black women were systematically left out of the processes of artmaking and productions. While black consciousness theatre from the 1970s to present have centered black male experiences, and feminist aesthetic focuses on white females' creation. Black women have had to create their own spaces where the image of the black female is center-stage. In creating a play with domestic workers, song, therefore, became a collective story-making process-black feminist theatre-making aesthetic as a political project.

In defining black feminist aesthetics, Lisa Anderson (2008) writes that this is work that intersects the lives of being black, woman and extending to the use of space. Black feminist aesthetic work invokes a particular history and politics that centers women. It is a "celebration of black women's identity, a focus on black subjects, and an interest in the way domestic space shapes the public sphere" (Thorsson, 2015, p. 151). Black feminist theatre aesthetic is a meeting place of theory and foregrounds the lives of black women (Anderson, 2008). The particularity of the aesthetic is the focus on the domestic space for black women as a space of empowerment. Theatre becomes a space where story can be told through different art forms; acting, singing, moving, or painting, the story is there. Dipina tsa Monyanyako allowed for the use of songs as stories that narrate the interior lives of women.

\section{Rehearsals: song as an expression of care and anger}

The following song, Sinqanda amayeye, was sung during rehearsals. Sinqanda amayeye means: we are preventing chaos. Historically the song has been sung in political movements and unions. The song, in particular, was sung at the ANC 2008 National conference. According to researcher Janet Cherry (2015), the song was sung as a reflection of the divisions and factions within the party at the time.

\section{Sinqand'mayeye}

\begin{tabular}{|l|l|}
\hline Sinqand'mayeye, & We are preventing chaos/disorder \\
Amayeye, & Chaos \\
Amayeye (sinqand'mayeye) & We are preventing chaos/disorder \\
Izolo bekumnandi & Yesterday it was lovely \\
Namhlanje kuyaliwa & Today we are fighting \\
sinqand'mayeyeye & We are preventing chaos \\
\hline
\end{tabular}

The song is rhythmical, with tempos of militancy. It was sung while clapping and stamping. It is reminiscent of Xhosa battle songs. I had heard the song been sung in union meetings and various other versions in student protests. The change in particular to students' protest was:

\begin{tabular}{|l|l|}
\hline Izolo besifunda & Yesterday we were learning \\
Namhlange kuyaliwa & Today we are fighting \\
sinqand'amayeye & We are preventing chaos \\
\hline
\end{tabular}


However, in our rehearsals, it was remixed by the younger women as a way of moving from the daily religious songs we sang in the group, and as an offering of a fun song we might include in the final play.

\begin{tabular}{|l|l|}
\hline $\begin{array}{l}\text { Sinqand'ma voetsek uyeye } \\
\text { Amayeye }\end{array}$ & $\begin{array}{l}\text { We are preventing fuck you } \\
\text { chaos/disorder }\end{array}$ \\
Amayeye (sinqand'mayeye)... & \\
\hline
\end{tabular}

The song was not included in the final piece but a discussion of it is necessary as it was sung religiously in the rehearsals. It was left out of the final show, due to its militancy. BoMama said they were not trying to rally each other politically. Most of them worked six days a week with one day off, mostly Thursday or Friday. Though they acknowledge the injustices, they did not want the creative space to become about complaining about work. They rathered a place of rest and one where they were getting away from work since they worked in people's homes all day and evening, as livein domestic workers/cleaners/logistics. They did not have a time where work stopped. Therefore, the meetings were a space of reprieve. They were also clear from the onset that they were not interested in organizing themselves politically (i.e., on fighting for better wages). They didn't want to rock the boat. Not everyone agreed, but most people were clear on this. So, it was respected. The song functioned as an expression of some anger. Anger in everyday life:

Sinqand'ma voetsek uyeye

We are preventing fuck you chaos/disorder.

This remix suggests that one is preventing "fuck yous" that can result from chaos. In this sense, the idea that during their everyday life, at work, and even in the group, they preventing "Fuck Yous" from happening. This echoes that for black women, anger is too dangerous. So, the work they do is to consistently dissuade it from being expressed. Singing this song in particular, was to make present the anger that exists and it encapsulates a gesture of sweeping away. There was anger about not having lights at the center, anger over their family issues, anger about work, etc. their song comes from what has happened, but also allows the BoMama to experience the anger without it being an over-consuming emotion.

The songs sung in rehearsals and the final production were not original compositions; they were songs that emerged from improvisations and some were known to most. The songs conjured historical and present realities. They were an opening for sharing of stories that were associated with the song. These then led to improvisations of stories and short skits. The melodies functioned as both transition strategies; background vocals for stories but also as a group and collective ritual for creating. An attempt on my part to write out the whole script has been met with many fraught mishaps. The final product was a play with three skits, interspersed with songs. It was not a musical. More of a collection of songs that were interrupted by stories. The songs played an important role for messaging, since the skits were varied; the songs helped to link the stories together.

\section{The Skits}

- Ijob yijob was about family feud and how unemployment affected a family

- Mama's got a boyfriend not a job! was about a domestic worker's fraught relationship with her children.

- When Thuli changed was about the impact of drugs on a family

The play was made for performance and not easily published. Singing allowed for the rehearsal space to be democratic, a sort of give-and-take, call and response where everyone was involved as an artist. The collaborative nature of singing allows for 
everyone to use their body and be present in the play, even if they were not core characters in the skits. Singing forced the expression of the body.

\section{Songs in the play}

Dipina tsa Monyanyako opened with Iyeleyele siyenza njena as BoMama entered from the back of the venue (behind the audience). They then made their way to the front of the room singing the song.

\section{Iyele yele siyenza njena (isiZulu)}

\begin{tabular}{|l|l|}
\hline Iyeleyele siyenza njena & It's fine we are doing it like this \\
Iyeleyele (iyeleyele) & It's just fine \\
Iyeleyele (iyeleyele) & It's just fine \\
Iyeleyele (iyeleyele) & It's just fine \\
Iyeleyele siyenza njena & It's fine we are doing it like this \\
\hline
\end{tabular}

The song acted as an introduction of sorts, stating clearly: This is who we are, and this is what we do! More importantly, it spoke to ally our fears; mine and BoMama. The fear was: "What would people say about this play?" As co-creators we were acutely aware that the play did not fulfil the common aesthetical elements of a play, which were a clear script with clear characters and roles. A play with guidelines on story, costuming and lighting. Dipina tsa Monyanyako was an opportunity to create anew what would a successful play look like for the group? For BoMama, it was a piece that they could share their hearts with their friends, and especially their children. Care in this instance was marked by the collective creation and collective meaning-making of the production. The play was an improvisation that shifted from day to day and rehearsals to performance. The only constant in the artwork were the songs. These stayed the same. These were sung to punctuate action or stop an improvisation from going on too long.

The opening song, declaring that "this is what we do," was sung with confidence and enthusiasm to propel them into the performance space. A similar song with praise properties was MaBerrario. Here the line between song and praise poetry was blurred. Praise poetry and singing is a heroic recital. The praise poetry is a particular oral poem recited to honour a people, a tribe, self or a leader and even nature; animals and landscape are praised. The poetry is about admiration (Jadezweni, 1999).

\section{MaBerrario (SeSotho)}

\begin{tabular}{|l|l}
\hline MaBerarrio, (MaBerarrio) & Women of Berarrio (Lead singer) \\
MaBerarrio (MaBerarrio) & Women of Berarrio (backing vocals) \\
Hare kopaneng & Let's come together \\
Batla sala ba botsana bare bale ke bo mang & They will be left asking each other: \\
Ke BoMme BaBerarrio & “Who are those women?” \\
& They are women from Berarrio.
\end{tabular}

BoMme created this song for the group itself. It was sung like a praise poem. It provided a moment to think of what the audience or other people may think of them, as a group. The song rallies the group. The song is sung in a loud voice. The lead singer started it as a command: "MaBerrario!" The utterance of this one word rallied the women to remember that they are women who are empowered. This song was created by BoMme for their group. It was a song they first sang for me. It's like a praise 
poem of sorts. They sang it with a lot of pride. It is like a war cry, a song that foretells that they are here. They exist and they have something to say and do in the world. The song is an assertive song that speaks also to a performative-ness that someone is watching. An audience is watching and will be left asking themselves, "Who are these women?" This question is one of awe, wonder and possibility. It removes the robe of an oppressed worker to someone of wonder. The self-praise song is a response to some really hard experiences of daily living. The song as a creation is a shield against dependency and exploitation, but a rallying call towards changing something that will lead to even bystanders asking themselves, "Who are these women?"

Regarding composition, historically in South Africa, women are not named as composers to songs. In the anthropological book, In the time of Cannibals:The word music of South Africa's Basotho migrants, Coplan (1994) offers a look at how Basotho women who created and were part of a musical genre called the shebeen songs (bar songs). Shebeen songs were songs sung in particular in shebeens (informal bars). He doesn't name the women as composers, though the songs, unlike the male songs, have clear titles. He suggests that the women are seen as a collective. He writes that shebeen songs were kept generic and not accorded to one person in order to "avoid public criticism from men. Basotho women were not interested in identifying and thus being singled out for condemnation for a genre" (Coplan 1994, p. 158). We see here the choice by black women who want to be part of a collective, rather than be singled out. The genre of shebeen songs can be linked closely to Dipina tsa Monyanyako, and different to Difela, which were and are related to church songs. The migrant women coming and living in South Africa used songs to encode their experience. In the following song that was sung in the play, it seems to hark back to the shebeen songs. The song is about a mother bemoaning the effects of alcohol, drugs and the dangers that children face when they go out at night. The song is a sort of complaint but sang in an upbeat tempo, to blend into the content and lyrics around beer.

\section{Jwalane mantsiboea (SeSotho)}

\begin{tabular}{|l|l|}
\hline Jwalane, & Small beer \\
Mantsiboea ee & In the evening \\
Jwalane, & Small beer \\
Mantsiboea ee & In the evening \\
ee mantsinboea ee (backing vocals) & Yes at night (backing vocals) \\
Bana ba rona (ee ke mantsiboea) & Our Children (Yes at night) \\
Ke di tsotsi & They are thugs \\
Banwa bo jwala" & They are drinking alcohol \\
\hline
\end{tabular}

The song works to make the singer and the audience think about the lyrics. When BoMama sang the song, they also found a communal strength, because the fear and worry about children, who they don't live with, was a shared anxiety. The song demonstrates how song was used as reflection and a form of social action.

\section{Language in the songs}

The choice of language revealed the very urban nature of the group. Dipina tsa Monyanyako was a depiction of stories interspersed by song. These stories were as diverse as the languages spoken in the room. Most of BoMama were Tswana speaking, Sesotho and Sepedi, with a few Zulu speakers, and one was from Zimbabwe, two from Mozambique and one from Malawi, who spoke Shona, Portuguese with Tsonga and Chiwa. As a group we moved between SeSotho and English. BoMama would translate Tswana conversations to Zulu for the ones from Malawi, since the Zimbabwean 
and Mozambicans could understand. I never acted as a core translator. I assumed that they had created the group themselves, so the mix in language must also be worked out by the group. However, the mix of languages sometimes caused a tower of babel as language was contentious. When it came to the choices and selection of songs, the Sesotho songs were easily selected since most of BoMama were Sesotho speakers. One day there was a fight over how the group was singing one song. The older woman-an 80-year-old who had suggested the song-felt that they were singing it wrong. Mispronouncing the words and being lazy to add power and vigor to the song. She threatened that she would take away the song. The group then decided to suggest other songs as a way of overriding her outburst. The song that was suggested was a Xitsonga song, and the rhythms were hard. When BoMama failed to learn the song, the owners of the song started chatting in Xitsonga. Then, the Zulu-speaking group also held their caucus and finally the group was divided into four groups, all speaking their language. But I could see the nervousness from the 80-year-old who finally sang the one song they all really liked and sang well. This eased everyone back into the song.

When asked to reflect on what happened and the choices in language and the challenge they all faced. They reflected that they were all being pushed to speak a certain language in Johannesburg. In the workplace it was English, at the taxi rank it was Zulu, and now the group was also bullying them to speak one language. Language in South Africa has been a site of contention. In 1976, Soweto school children took to the streets to protest against the use of Afrikaans as a medium of instruction. The idea that one language can dominate social interactions brings about anxiety and apprehension in the collective. So, for BoMama language was important. The song also worked as a unifying language, though there were complaints about the choices. The language challenge then led me to encourage the ones with really clear ideas on what they want to say to create poems that speak to their language, but at the same time, engage with the group and what they are all working on. From this moment, we used a Setswana Poem to kick-off the play, then a Sepedi praise poem towards the middle and a Xitsonga song with a dancer at the end of the play. From creating in their language, BoMama surprised each other with their performances and abilities. One woman, Mama Joyce, remarked that she had never taken a leadership role, and now she was leading the whole play with a Setswana poem.

Another conversation on language that we had was on the choice of language the whole action and dialogue of the play would be in. Some of BoMama wanted the play in English. But Mama Sylvia asked who the play was for. Was it for them or the employer? She suggested that if the play was made into English it meant that they were centering their employers. It meant they were assuming that in the audience, filled with friends and family, their white employers would attend, and they were so important that the play would need to shift for them. This for me was a very key moment, as she was asserting that the meetings at Berrario Scouts Hall were for the women, and it was a space to rest, be safe and away from work. By making their play in English, it meant they were bringing work into this personal space. It would mean that the story also would be different to accommodate the employer and their ideas of them. We, collectively, then decided the play will be in the languages spoken in the room. This served the story far better, as the audience were friends and family who understood all the languages spoken.

The creative production from the anger that language difference caused was the ability to recognize the differences as creative tools. Rather than letting it become part of distortions, lines of difference were drawn that allowed the anger to transform the space in a way that allowed for insight and new stories and creation. They were able to express anger to each other, this Lorde (1981) remarks, "Anger between peers' births change, not destruction, and the discomfort and sense of loss it often causes is not fatal, but a sign of growth" (p. 283). What was also particular about language was that BoMama had clear guidelines-directorially-on how roles/characters should say certain things. They would direct each other on tones. Age, occupation, and gender fitting language. The performance of language in this regard became communal and collective 
creation. Attached to language is what the group creates as meaning. Ngugi wa Thiongo (1986), in his book, Decolonizing the Mind, relays the story of how the community co-created the play, I'll Marry When I Want. In his engagement, he shares that the role of language in the process of creation is one that not only conceptualizes identity, but also social roles and actions (Thiongo, 1986). Meaning that not only is their creation of the show, but also a creation of a common performance language that enables everyone to act, and perhaps enables a form of social action.

\section{Political lullaby}

The following song became popular in the South African political scene in 2017, in the run up to the ruling party, the African National Congress', presidential elections. Historically, it's a lullaby where the singer-a mother-comforts her baby and assures them that things will change. In 2017, ANC delegates adopted a comforting recital to comrades who wanted a change in the leadership. It is not a political song. Therefore, it was welcomed in the production as a song that mothers could sing and reflect on.

The lead singer declares that things will change. Because it is easy to learn and it was already known in the public, the song appealed to the group in order to include the audience to sing along.

\section{Wena ukhalelani? (isiZulu)}

\begin{tabular}{|l|l}
\hline Zizo Jik'izinto & Things will turn around (lead) \\
Thula mntanami & be still my child, (Backing vocals) \\
Wen Ukhalelani & Why do you cry? \\
Thula mntanami & be still my child, \\
Wen Ukhalelani & Why do you cry? \\
Isikhalo somntwana sihoye & a child's cry must be tended to \\
Thula mntanami & be still my child
\end{tabular}

\section{Sifubeng sa darly (SeSotho)}

Sifubeng sa darly/Sebaka nyana was made famous in the 1970s by jazz vocalist Abigail Khubeka. I remember hearing the songs as a child sung at weddings and choir competitions. There are various versions of the songs. In 2003, Afro-Pop music group Malaika released amalgamation of the song that became the anthem for wedding dances and adult parties.

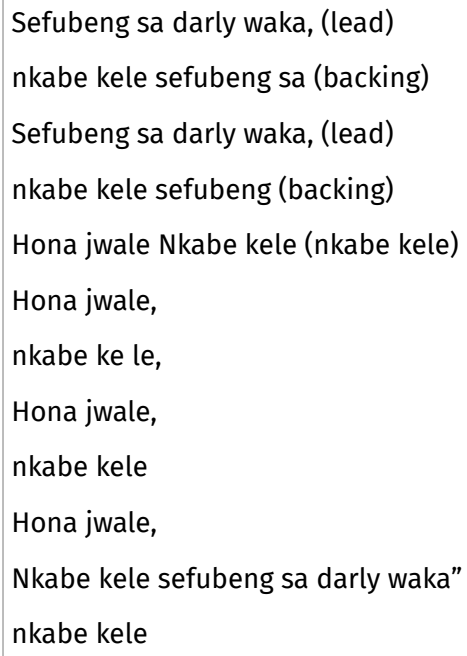

On my lover's chest

I should be lying on that chest

On my lover's chest

I should be lying on that chest

Now, I should be

Right at this moment

I should be

Right at this moment

I should be

Right at this moment

I should be on lying on the chest

of my love 
The song was one that was enjoyed by all who sang and heard of it; one, because it is familiar, and two, because it was one of the lighter and about love. The song speaks about a lover and possible rest. The domestic worker image is one of the obedient black women. "She is asexual. Therefore, she poses neither threat to the mistress nor temptation to the Master" (Simms, 2001, p. 882). In this mold, the lives of BoMama could be easily reduced to the known role of worker and invisible. However, through the songs above about nightlife where drinking and life happens, including having a lover, the songs revealed that BoMama were more than asexual beings. They have desires to be loved and held. Sebaka nyana is sung with bravado and demand, with an elaborate high pitch when asserting, "Hona, Jwale!" [right now]. The song also is heart-breaking as it reflects and responds to the physical hardships and separation of lives split between work and home. The song revealed that BoMama were also willing to sit in the uncomfortable. The song sits in a space of desperation. The singer holds a quiet dignity by her own admission.

\section{Conclusion}

This paper raises a number of themes regarding the role of song as an element of black feminist aesthetic. I argue that women's performances of song and theatre-making are closely linked to expressions on everyday issues. Dipina tsa Monyanyako was, for all intents and purposes, a workshop/ community theatre play. It was not scripted. The actors were given roles as opposed to characters (Hutchison, 1996). It was made in community. What is important for this article is that the play also drew on traditional aesthetics forms such as singing, praise poetry and storytelling. The process of creating rejected conventional theatre-making practices that allowed for other performance forms such as music, narrative and dance. It is a form of black feminist theatre-making aesthetic since the central theme was women's experiences.

The play attempts to offer insight into the significance of black feminist aesthetics to healing processes. Being engaged in this work revealed to me that research rhetoric is inadequate in capturing song, poetics, and forms of performance that black women are engaged in. This paper has attempted to provide insight into the role of black women in South Africa. The performance of the play and songs serves as an expression of aspirations and expectations, care and anger, joys and sorrows. I suggest that performance is an important source of information of how black women imagine their role in society.

\section{About the author}

Refiloe Lepere is a black feminist playwright, theatre director, drama therapist, journalist and facilitator. Her work using therapeutic theatre weaves history, statistics and personal narratives to address issues of social (in)justice, trauma, intersectional identities of black women and the performance of labour. Her research looks at how race performs and thereby frames and shapes our understanding and interpretation of the world. She is a graduate of New York University and University of Witwatersrand, a Think Fellow and Ford Foundation Fellow. She currently lectures at Tshwane University of Technology, South Africa. Her work creates interconnections between race and feminist theory, social justice and theatre-making practices. She travels around the world hosting masterclasses on story as a social justice tool, and she has organized several major festivals and symposiums on Arts-in-Health in South Africa. 


\section{Notes}

1. I use BoMme, or BoMama (Mothers) because for me all older women are BoMama (mothers); a sign of respect. Nigerian theorist Ife Amadiume (2015) writes that motherhood is not the preserve of those who have given birth but is a concept that is shared across society, even gender. In light of this and my own upbringing, they are BoMama. In our work together we became close, which is the ethical dilemma of being human, right? Theatre's collaborative nature blurred the director-actor or researcher-participant.

2. This study took place between March 17, 2018 and May 21, 2020 and was approved by the Human Research Ethics Committee of the University of the Witwatersrand, Johannesburg. The six broad ethical considerations were engaged with, in the process of creating the play. Each woman involved in the study read and signed an informed consent statement consenting to participation in the playmaking. There were consistent explanations on the desires of the writer to create a play. This engagement was a collective negotiation. All participants gave informed consent to be part of the play. The caveat was to bring no harm to any of the members for their participation. In the article I try to discuss the ethics as a concept that moves beyond the mechanics of signed documents but also to ideas of ways of being in the room, allowing for a democratic way of creating and a reimagination of roles. The participants were made aware that the activities of the play will be used for a research report. The consent form stated that participants are consenting to dissemination of the research and further reports.

\section{References}

Amadiume, I. (2015). Male daughters, female husbands: Gender and sex in an African society. Zed Books.

Anderson, L. M. (2008). Black feminism in contemporary drama. University of Illinois Press.

Cherry, J. (2015). Emzabalwazweni: Singing the language of struggle, past and present. In M.

N. Dedaic (Ed.), Singing, speaking and writing politics: South African political discourses (pp.

221-246). John Benjamins Publishing Company. https://doi.org/10.1075/dapsac.65.10che.

Coplan, D. B. (1994). In the time of cannibals: The word music of South Africa's Basotho migrants. University of Chicago Press.

Futhwa, F. (2011). Setho: Afrikan thought and belief system. Nalane Ka Fezekile Futhwa.

Gqola, P. (2006). Crafting epicentres of agency: Sarah Baartman and African feminist literary imaginings. Quest: An African Journal of Philosophy, XX(1-2), 45-76.

Hartman, S. (2008). Venus in two acts. Small Axe: A Caribbean Journal of Criticism, 26, 1-14, https://doi.org/10.1215/-12-2-1.

HBBO - Berarrio Women's Group. (2018). Interviews, Dipina tsa Monyanyako [Unpublished play script].

Hutchison, Y. (1996). "Access to rather than ownership of": South African theatre history and theory at a crossroad. South African Theatre Journal, 10(1), 35-47, https://doi.org/10.1080/ 10137548.1996.9687646.

Hirsh, L. (2003). Amandla!: A revolution in four part harmony [Film]. Kwela Productions.

Jadezweni, M. (1999). Two Xhosa praise poets in performance: The dawn of a new era. Institut für Afrikanistik, Universität Leipzig.

Lorde, A. (1981). Uses of anger: Women responding to racism. CUNY Academic Works.

Mkhoma, T. (2017). Songs and storytelling - A therapeutic theatre-making process as a tool to heal the wounds of the past [Unpublished master's thesis]. Wits University Wiredspace.

Motsemme, N. (2004). The mute always speak: On women's silences at the Truth and Reconciliation Commission. Current Sociology, 52(5), 909-932, https://doi.org/10.1177/ 0011392104045377.

Muyanga, N. (2015). Make Poor Opera - An Injunction to transform the genre yet again, only this time from the South [Draft paper]. 
Simms, R. (2001). Controlling images and the gender construction of enslaved African women. Gender and Society, 15(6), 879-897.

Thiongo, N. (1986). Decolonizing the mind: The politics of language in African literature. James Currey Heineman.

Thorsson, C. (2015). Gwendolyn Brooks's black aesthetic of the domestic. MELUS, 40(1), 149-176, https://doi.org/10.1093/melus/mlu062. 